\title{
Peningkatan Kreativitas Anak Kelompok B1 Melalui Kegiatan Menghias Menggunakan Teknik Kolase Payet
}

\author{
Anggita Yola Prastika \\ Universitas Negeri Malang - Jalan Semarang 5 Malang 65145 \\ E-mail: anggitayola2@gmail.com.082245660177 \\ Usep Kustiawan \\ Universitas Negeri Malang - Jalan Semarang 5 Malang 65145 \\ Rosyi Damayani Twinsari Maningtyas \\ Universitas Negeri Malang - Jalan Semarang 5 Malang 65145
}

\begin{abstract}
The research objective was to find out (1) the implementation of teacher learning in the application to enhance creativity through decorating activities using sequin collage techniques, (2) increasing creativity through decorating activities using sequin collage techniques. Data is collected by observation, interview and documentation techniques. Data analysis was carried out in a qualitative descriptive manner about child and teacher activities, interviews, field notes and documents and quantitatively about improving children's creativity. Researcher's results are: (1) implementation of teacher learning in application to enhance creativity through decorating activities using sequin collage techniques, (2) decorating activities using sequin collage techniques can increase creativity.
\end{abstract}

Keywords: Creativity, Sequin Collage Technique, Children Aged 5-6 Years

\begin{abstract}
Abstrak
Tujuan penelitian ini untuk mengetahui (1) pelaksanaan pembelajaran guru dalam penerapan untuk meningkatkan kreativitas melalui kegiatan menghias menggunakan teknik kolase payet, (2) peningkatan kreativitas melalui kegiatan menghias menggunakan teknik kolase payet. Data dikumpulkan dengan teknik observasi, wawancara dan dokumentasi. Analisis data dilakukan secara deskriptif kualitatif tentang aktivitas anak dan guru, wawancara, catatan lapangan dan dokumen dan secara kuantitatif tentang peningkatan kreativitas anak. hasil peneliti adalah: (1) pelaksanaan pembelajaran guru dalam penerapan untuk meningkatkan kreativitas melalui kegiatan menghias menggunakan teknik kolase payet, (2) kegiatan menghias menggunakan teknik kolase payet dapat meningkatkan kreativitas.
\end{abstract}

Kata kunci: Kreativitas, Teknik Kolase Payet, Anak Usia 5-6 Tahun. 


\section{PENDAHULUAN}

Pada masa usia dini, semua potensi anak berkembang sangat cepat dan setiap anak mempunyai potensipotensi yang harus dikembangkan. Salah satu potensi yang harus dikembangkan yaitu kreativitas. Menurut Rothemberg (1976) (dalam Mutiah, 2015:42) kreativitas adalah suatu proses mental seorang anak untuk melahirkan gagasan, ide, proses ataupun produk baru yang bersifat imajinatif yang berguna dalam berbagai bidang untuk pemecahan masalah. Maka dari itu perlu adanya upaya untuk meningkatkan kemampuan kreativitas yang di miliki anak sejak usia dini secara baik dan optimal. Mengembangkan kreativitas perlu adanya peranan dari guru. Menurut Rachmawati dan Euis (2012:31) "guru memegang peranan lebih dari sekedar mengajar, melainkan pendidik dalam arti yang sesungguhnya. "Kemungkinan siswa melakukan proses identifikasi peluang untuk munculnya kreativitas sebagian besar adalah dari guru yang kreatif pula. Guru yang kreatif adalah guru yang mampu menggunakan berbagai pendekatan dan stimulus dalam kegiatan belajar dan membimbing siswanya. Untuk mendorong kreatifitas diperlukan sikap yang demokratis dari seseorang yang terbentuk dari lingkungan pendidikan nonformal (Laksono, 2017)

Berdasarkan observasi di kelompok B TK Dharma Wanita Persatuan 1 Purwoharjo Ampelgading Malang yang di lakukan pada bulan Agustus 2018, peneliti mengobservasi serta mewawancarai guru kelas kelompok B dan menunjukkan bahwa $50 \%$ perkembangan kreativitas anak belum berkembang dengan baik. Dari hasil pengamatan yang dilakukan di kelompok B TK Dharma Wanita Persatuan 1 Purwoharjo Ampelgading Malang terdapat permasalahan dalam peningkatan kreativitas anak yaitu dari jumlah 18 anak, terdapat 9 anak yang kreativitasnya belum berkembang dengan optimal, hal ini terlihat dari hasil karya yang telah di buat oleh anak. Hasil wawancara pada guru kelas kelompok B adalah bahan yang digunakan untuk meningkatkan kreativitas anak kurang bervariasi. Sebagaimana dalam kegiatan kolase, bahan yang digunakan hanya seperti biji-bijian dan kertas. Jadi, pada saat anak melakukan kegiatan kolase anak menjadi kurang bereksplorasi, kurang berimajinasi, tidak menyesaikan tugasnya dan anak masih belum bisa berkreasi sendiri, masih mencontoh temannya.

\begin{tabular}{lrr}
\multicolumn{2}{c}{ Berdasarkan } & pemaparan \\
permasalahan tersebut & peneliti \\
memberikan alternatif & dengan
\end{tabular}
menggunakan kegiatan menghias menggunakan teknik kolase payet pada anak kelompok B TK Dharma Wanita Persatuan 1 Purwoharjo Ampelgading Malang. Pelaksanaan kegiatan dapat disesuaikan dengan tema yang diterapkan disekolah dan menggunakan berbagai macam warna serta bentuk payet yang akan digunakan. Kegiatan menghias menggunakan teknik kolase payet akan menjadi hal yang sangat menarik. Menurut Haryanto 
(2010) (dalam skripsi Andriani 2014:23) menyatakan bahwa kegiatan kolase tidak hanya meningkatkan kreativitas anak tetapi juga akan meningkatkan kemampuan anak menyelesaikan masalah, melatih fisik motorik halus, mengenal warna dan bentuk, melatih kesabaran, melatih konsentrasi dan imajinasi, belajar menempel dengan rapi, melatih kelenturan otot-otot dan koordinasi tangan dan mata serta mengembangkan rasa percaya diri pada anak.

$$
\text { Kegiatan menghias }
$$

menggunakan teknik kolase payet diharapkan dapat meningkatkan kreativitas anak usia 5-6 tahun di TK Dharma Wanita Persatuan 1 Purwoharjo Ampelgading Malang. Melalui kegiatan ini juga dapat dijadikan bahan referensi oleh guru untuk melakukan kegiatan meningkatkan kreativitas dengan menarik dan meneyenangkan bagi anak. berdasarkan pemaparan latar belakang di atas maka akan dilaksanakan penelitian dengan judul "Peningkatan Kreativitas Anak Kelompok B melalui Kegiatan Menghias Menggunakan Teknik Kolase Payet di TK Dharma Wanita Persatuan 1 Purwoharjo Ampelgading Malang"

\section{METODE}

Penelitian ini menggunakan Penelitian Tindakan Kelas (PTK) dengan model kolaboratif yaitu melibatkan satu orang guru sebagai kolaborator. Sebagaimana dikemukakan oleh Arikunto (2013:
138) yaitu "penelitian tindakan kelas yang baik adalah apabila dilakukan dalam bentuk kolaborasi”. Penelitian ini menggunakan model yang dikembangkan oleh Kemmis \& MC. Taggart dalam Akbar (2009:28). Pelaksanaannya dilakukan selama dua siklus dengan dua pertemuan setiap siklusnya. Tahapan yang terdapat pada siklus ini terdiri dari perencanaan, pelaksanaan, pengamatan, refleksi dan perbaikan rencana. Subjek penelitian ini adalah peserta didik pada kelompok B1 TK Dharma Wanita Persatuan 1 Purwoharjo Ampelgading Malang dengan jumlah peserta didik 18 anak yang terdiri dari 11 anak laki-laki dan 7 anak perempuan. Jika pada siklus satu belum dapat menyelesaikan permasalahan, maka akan diadakan siklus dua dengan cara perbaikan dari hasil refleksi pada siklus 1. Teknik yang digunakan dalam pengumpulan data yaitu teknik observasi, wawancara dan dokumentasi. Data yang digunakan berupa data aktivitas anak, aktivitas guru, data peningkatan kreativitas anak, data wawancara, data dokumentasi dan cacatan lapangan. Peneliti menggunakan analisis data kuantitatif dan analisis data kualitatif yang meliputi data peningkatan kreativitas anak sebagai data kuantitatif dan wawancara, catatan aktivitas anak, catatan aktivitas guru serta catatan lapangan sebagai data kualitatif.

Analisis data kualitatif menggunakan tahapan yang dimulai dari pengumpulan data, penyederhanaan data penyajian dan 
kesimpulan. Semua data kualitatif diperlukan dan di analisis untuk mendapatkan kesimpulan dari seluruh data yang diperoleh. Data kuantitatif dianalisis dengan menggunakan rumus yang diwujudkan dalam nilai persentase menurut Trianto (2010:214) sebagai berikut:

\begin{tabular}{clc}
\multicolumn{3}{c}{ Tabel 1. Kriteria ketercapaian kelas } \\
\hline $\begin{array}{c}\text { Interval } \\
\text { Presentasi }\end{array}$ & Keterangan & $\begin{array}{c}\text { Kriteria } \\
\text { Nilai }\end{array}$ \\
\hline $85 \%-100 \%$ & Sangat & BSB \\
& Tercapai & \\
$75 \%-84 \%$ & Tercapai & BSH \\
$38 \%-74 \%$ & Mulai & MB \\
& Tercapai & \\
$0 \%-37 \%$ & Belum & BB \\
& Tercapai & \\
\hline
\end{tabular}

Mengacu pada kriteria yang telah ditentukan maka batas minimal nilai keberhasilan dalam penelitian ini adalah $75 \%$. Persentase ketercapaian kemampuan motorik kasar akan dikatakan tercapai apabila mencapai nilai $75 \%-100 \%$.

\section{HASIL DAN PEMBAHASAN}

\section{Hasil}

Observasi awal dilaksanakan oleh peneliti pada bulan Agustus 2018 di TK Dharma Wanita Persatuan 1 Purwoharjo Ampelgading Malang. Kegiatan yang dilakukan sebelum memasuki ruangan yaitu berbaris dengan rapi di halaman sekolah sambil bernyani-nyanyi dan menggerakkan anggota badan. Setelah itu anak memasuki ruangan kelas dan pada kegiatan awal di dalam kelas guru mengucapkan salam guru mengucapkan salam selanjutnya guru mengajak anak untuk berdoa sebelum belajar dan membaca surat- surat pendek bersama. Setelah itu guru melakukan absensi dan melakukan percakapan mengenai aktivitas yang dilakukan anak pada pagi hari. Setelah itu guru melaksanakan kegiatan pembelajaran yang berkaitan dengan tema hari ini. Peneliti berfokus pada proses kegiatan pembelajaran anak yang dapat meningkatkan kreativitas anak yang dilaksanakan di sekolah.

Berdasarkan pengamatan menunjukkan bahwa 50\% perkembangan kreativitas anak belum berkembang dengan baik. Dari jumlah 18 anak terdapat 9 anak yang kreativitasnya belum berkembang dengan optimal. Hal ini terlihat dari hasil karya yang telah dibuat oleh anak. Hasil wawancara pada guru kelas kelompok B adalah bahan yang digunakan untuk meningkatkan kreativitas anak kurang bervariasi. Sebagaimana dalam kegiatan kolase, bahan yang digunakan yaitu seperti biji-bijian dan kertas saja. Jadi, pada saat anak melakukan kegiatan kolase anak menjadi kurang bereksplorasi, kurang berimajinasi, tidak menyelesaikan tugasnya dan anak masih belum bisa berkreasi sendiri, masih mencontoh temannya.

\begin{tabular}{ccc}
\multicolumn{2}{c}{ Pelaksanaan } & siklus \\
dilaksanakan selama & dua & kali
\end{tabular}
pertemuan. Hasil dari pertemuan pertama hingga kedua menunjukkan hasil yang belum berkembang. Anak belum mampu mengerjakan kegiatan menghias menggunakan teknik kolase payet dengan baik meskipun telah dicontohkan oleh guru dan peneliti. Hal tersebut dikarenakan dalam melakukan kegiatan menghias 
menggunakan teknik kolase payet diperlukan waktuyang lebih banyak untuk anak-anak berlatih dan mengulang-ulang kegiatan dan kegiatan ini merupakan hal yang baru dilakukan oleh anak. Oleh karena itu banyak anak yang belum mencapai hasil peningkatan yang baik dan optimal. Adapun persentase perolehan hasil peningkatan kreativitas pada pertemuan pertama siklus I adalah $25 \%$ dengan kategori "Belum Tercapai". Hasil persentase pada pertemuan kedua siklus I mencapai hasil 50\% dengan kategori "Mulai Tercapai”. Hingga pertemuan kedua ini masih menunjukkan persentase kelas dengan kategori yang belum tercapai tetapi setiap pertemuan anakanak mengalami perubahan dan mengalami peningkatan. Hal tersebut membuktikan bahwa melalui kegiatan menghias menggunakan teknik kolase dapat meningkatkan kreativitas anak. Akan tetapi hasil akhir dari pertemuan kedua belum memenuhi standar ketercapaian yang diharapkan.

Berdasarkan refleksi pelaksanaan siklus I dengan dua kali pertamuan maka peneliti dan guru mendiskusikan perbaikan yang akan dilakukan pada siklus II. Adapun perbaikan yang dilakukan adalah: 1) memberikan gambar yang lebih menarik untuk kegiatan menghias menggunakan teknik kolase payet agar anak-anak lebih semangat untuk melakukan kegiatan, 2) dan perbaikan kedua adalah menggunakan payet yang lebih banyak macamnya.

$$
\text { Pelaksanaan kegiatan }
$$
menghias menggunakan teknik kolase payet pada pertemuan pertama siklus II memperoleh persentase ketercapaian kelas sebesar 81,25\% dengan kategori "Tercapai". Pertemuan kedua pada siklus II mencapai hasil persentase sebesar $87,5 \%$ dengan kategori "Sangat Tercapai". Pelaksanaan siklus II telah menunjukkan adanya peningkatan yang sangat signifikan dan hasil yang dicapai telah melebihi standar ketercapaian yang diharapkan $\geq 75 \%$. Hal yang paling mempengaruhi adalah anak sudah empat kali mengulang-ulang kegiatan sehingga anak sudah mulai terbiasa dengan kegiatan menghias menggunakan teknik kolase ini. Anak sudah lancar dalam mengerjakan kegiatan, serta terlihat anak sudah dapat mengembangkan kreativitas dan daya imajinasinya. Anak dapat meningkatkan proses kreativias tersebut. Selain itu tidak lepas dari usaha guru yang membimbing dan membantu anak untuk melakukan kegiatan menghias menggunakan teknik kolase payet agar kreativias anak dapat meningkat dengan baik dan optimal. Melihat adanya perubahan yang di alami oleh anak dari pelaksanaan siklus I dan II yang sangat signifikan maka dapat disimpulkan bahwa kegiatan menghias menggunakan teknik kolase payet dapat meningkatkan kreativitas anak usia 5-6 tahun (Kelompok B1) di TK Dharma Wanita Persatuan 1 Purwoharjo Ampelgading Malang. 


\section{Pembahasan}

Peningkatan kreativitas anak usia 5-6 tahun melalui kegiatan menghias menggunakan teknik kolase payet di rancang menggunakan indikator yaitu: originality (keaslian), flexibility (keluwesan), fluency (kelancaran), elaboration (kerincian), sensitifity (kepekaan). Hal tersebut juga sesuai dengan yang telah dipaparkan oleh Parnes (dalam Rachmawati \& Euis 2012:14) proses kreatif akan terjadi jika dibangkitkan melalui masalah yang memacu pada lima macam perilaku kreatif yaitu originality (keaslian), flexibility (keluwesan), fluency (kelancaran), elaboration (kerincian), sensitifity (kepekaan).

Hasil dari melatih kreativitas adalah supaya anak mampu memberikan respons yang unik atau luar biasa yang berbeda dengan orang lain. Anak menjadi mampu mendeskripsikan pengarahan ide secara terperinci untuk mewujudkan ide menjadi kenyataan. Anak juga menjadi peka menangkap dan menanggapi terhadap segala macam situasi. Anak memiliki kemampuan untuk menghasilkan berbagai macam ide guna memecahkan suatu masalah di luar kategori yang biasa, dan mengembangkan dengan apa yang pernah dilihatnya. Anak menjadi lebih mampu mengemukakan ide yang serupa untuk memecahkan suatu masalah.

Langkah-langkah dalam upaya meningkatkan kreativitas anak melalui kegiatan menghias menggunakan teknik kolase payet adalah 1) menyiapkan bahan yang akan digunakan untuk kegiatan menghias menggunakan teknik kolase payet seperti kertas bergambar, lem, aneka macam payet dan lidi, 2) setelah itu menempelkan atau menyusun payet menggunakan lem pada kertas yang bergambar lalu menghiasnya. Sesuai dengan pendapat Sumanto (2011:177) yaitu : Persiapan, yaitu mengumpulkan dan memilih jenis bahan yang akan dibuat kolase. Mempersiapkan bidang dasaran, peralatan dan bahan pembantu. Pelaksanaan dengan langkah kerja: (1) untuk kolase dari bahan kertas berwarna atau kertas lipat terlebih dahulu dibentuk bagianbagian dari kolase yang kan di buat. Caranya bisa di gunting, di cocok atau dirobek sesuai bentuk/kesan obyek yang ingin ditampilkan, (2) kemudian dilanjutkan dengan melakukan penyusunan penataan sementara, (3) dilanjutkan dengan melakukan penyusunan tetap dengan cara merekatkan bagian-bagian bahan atau bentuk yang dipilih pada bidang dasaran, dan (4) penyelesaiannya yaitu dengan memberikan warna atau/cat agar hasil akhirnya lebih bagus, khususnya untuk kolase yang terbuat dari bahan alam. Untuk kolase dari bahan alam atau bahan limbah ada yang langsung dapat disusun tanpa harus di bentuk dahulu seperti halnya bahan buatan yang masih berupa lembaran atau utuh. Akan tetapi karena dalam penelitian ini menggunakan bahan yang sudah jadi, maka langkah-langkahnya hanya menempelkan payet pada kertas yang 
sudah bergambar menggunakan lem dan menghiasnya dengan rapi.

$$
\text { Kegiatan menghias }
$$

menggunakan teknik kolase payet sesuai jika diterapkan pada kelompok $B$ yang berguna untuk meningkatkan kreativitas anak. Karena tujuan dari teknik kolase itu bukan hanya sekedar meningkatkan kreativitas saja, tetapi sebagaimana telah disebutkan oleh Haryanto (2010) (dalam penelitian skipsi Andriani 2014:23) kegiatan kolase untuk anak usia dini mempunyai tujuan diantaranya adalah: 1) melatih motorik halus, 2) mengenalkan life-skill dasar, 3) melatih kesabaran dan kemandirian anak, melatih kemampuan menangkap bentuk dan warna objek, 4) melatih konsentrasi, kreativitas dan imajinasi, 5) belajar menempel dengan rapi, 5) melatih kelenturan otot-otot dan koordinasi tangan dan mata.

$$
\text { Pelaksanaan kegiatan }
$$

menghias menggunakan teknik kolase payet dilakukan pada saat inti pembelajaran. Berdasarkan pengamatan yang telah dilakukan oleh peneliti, guru telah melaksanakan sesuai dengan aturan yang disepakati antara antara peneliti dan guru. Guru menyampaikan di depan anak-anak dengan semangat dan antusias, memberikan contoh dengan sangat menarik. Hal tersebut dapat menjadi faktor yang mempengaruhi minat nak ketika akan melakukan kegiatan menghias menggunakan teknik kolase payet. Guru menjelaskan dari kegiatan awal pembelajaran mengenai kegiatan yang akan dilakukan pada hari ini, lalu masuk pada kegiatan inti dimana kegiatan menghias menggunakan teknik kolase payet dilaksanakan. Lalu di akhiri dengan kegiatan akhir dan melakukan refleksi.

Pertemuan pertama pada siklus I anak-anak masih merasa kesulitan untuk melakukan kegiatan menghias menggunakan teknik kolase payet mengikuti contoh yang telah di berikan oleh guru. Hingga pertemuan kedua masih banyak anak yang belum lancar mengerjakan kegiatan menghias menggunakan teknik kolase. Setelah di amati, hal tersebut terjadi karena kegiatan menghias menggunakan teknik kolase payet membutuhkan waktu yang lebih lama dan dilakukan secara berulang-ulang untuk melatih agar anak menjadi terbiasa dengan kegiatan terlebut. Karena kegiatan ini baru dilakukan jadi anak merasa kesulitan saat mengerjakannya.

Pertemuan pada siklus ke II peneliti melakukan perbaikan yaitu dengan memberikan gambar yang lebih menarik dan menggunakan payet yang lebih banyak macamnya. Hal tersubut dirasa perlu dikarenakan akan lebih membangun minat anak untuk lebih semangat dan tertarik dan melakukan kegiatan menghias menggunakan teknik kolase payet dengan optimal. Setelah peneliti melakukan penelitian selama dua pertemuan, peneliti memperoleh perubahan yang sangat signifikan dari siklus I ke siklus II. Hasil yang diperoleh meningkat dan sesuai 
dengan standar ketercapaian yang diharapkan oleh peneliti.

Berdasarkan pemaparan di atas maka dapat dikatakan bahwa melalui kegiatan menghias menggunakan teknik kolase payet dapat meningkatkan kreativitas anak. hal tersebut dapat terbuktikan melalui pelaksanaan kegaitan dari siklus I dan II. Pelaksanaan siklus I belum mencapai hasil yang baik dan optimal serta anak masih merasa kesulitan dalam mengerjakan kegiatan menghias menggunakan teknik kolase payet. Anak-anak membutuhkan penyesuaian waktu yang lama dan mengulang-ulang kegiatan tersebut. karena kegiatan ini merupakan hal yang baru dilakukan oleh anak. Setelah itu peneliti melakukan perbaikan pada siklus II dengan membrikan gambar yang lebih meraik agar anak senang dan semanagt mengikuti kegiatan pembelajaran, dan perbaikan yang kedua adalah menggunakan payet yang lebih banyak macam dan warnanya.

\section{PENUTUP}

\section{Simpulan}

Berdasarkan hasil penelitian tentang peningkatan kreativitas anak kelompok B melalui kegiatan menghias menggunakan teknik kolase payet di TK Dharma Wanita Persatuan 1 Purwoharjo Ampelgading Malang dapat disimpulkan sebagai berikut: kegiatan menghias menggunakan teknik kolase payet dilaksanakan pada inti pembelajaran, dengan menggunakan berbagai macam payet. Teknik kolase menggunakan payet tidak hanya meningkatkan kreativitas saja tetapi juga dapat melatih motorik halus anak, kesabaran, imajinatif, percaya diri dan juga aspek perkembangan lain, 2) Kegiatan menghias menggunakan teknik kolase payet mampu meningkatkan kreativitas dengan ketercapaian pada siklus II sebesar 87,5\%, 3) Dua anak yang belum bisa mengerjakan kegiatan dengan baik dan benar dikarenakan anak ini memerlukan bimbingan yang lebih dari guru dan membutuhkan waktu untuk latihan mengulang-ulang kegiatan menghias dengan menggunakan teknik kolase payet ini supaya anak tersebut dapat meningkatkan kreativitas seperti anak-anak yang lain..

\section{Saran}

Berdasarkan simpulan di atas, maka saran/rekomendasi yang diajukan sebagai berikut. Bagi sekolah penelitian ini dapat menjadi referensi dalam ilmu pengetahuan sekaligus memperkenalkan kegiatan menghias menggunakan teknik kolase payet sebagai salah satu kegiatan pembelajaran yang inovatif yang dapat meningkatkan kreativitas anak, khususnya anak usia 5-6 tahun atau kelompok B dan bagi peneliti selanjutnya diharapkan dapat meningkatkan dan mengembangkan inovasi yang lebih baru pada kegiatan menghias menggunakan teknik kolase payet baik dari alat dan bahan maupun cara dalam proses kegiatanny sehingga lebih menarik minat anak 
dan dapat meningkatkan kemampuan kreativitas anak.

\section{DAFTAR RUJUKAN}

Akbar, S. 2009. Penelitian Tindakan Kelas Filosofi, Metodologi \& Implementasi. Yogyakarta. Cipta Media Aksara

Andriani, Y. 2014. Peningkatan Motorik Halus Melalui Kegiatan Kolase pada Kelompok B di TK Yaa Bunayya Beru Wlingi Blitar. Skripsi tidak di terbitkan. Malang : FIP UM

Arikunto, S. 2013. Prosedur Penelitian Suatu Pendekatan Praktik. Jakarta : Rineka Cipta.

Laksono, B. A. (2017). Peran Pendidikan Nonformal Dalam Menumbuhkan Karakter Demokratis. Seminar Nasional Pendidikan: Sinergitas Keluarga, Sekolah, Dan Masyarakat Dalam Penguatan Pendidikan Karakter, 111-119. Mutiah, D. 2015. Psikologi Bermain Anak Usia Dini. Jakarta: Prenada Media Group.

Rachmawati, Y. \& Euis R, 2012. Strategi Pengembangan Kreativitas Pada Anak Usia Taman Kanak-Kanak. Jakarta: Kencana. 